\title{
The Effectiveness of Interpersonal Communication on Employees at Vocational High School YPLP PGRI 1 Makassar
}

\author{
Nurul Sazwani ${ }^{1}$, Jamaluddin ${ }^{2}$, Risma Niswaty ${ }^{3}$ \\ ${ }^{1,2,3}$ Universitas Negeri Makassar \\ Email: sazwani.nurl@gmail.com
}

\begin{abstract}
As human social beings in everyday life always want to relate to other humans. He wants to know the surrounding environment, even wants to know what is happening in him. This curiosity forces humans to communicate. This study aims to determine the effectiveness of interpersonal communication among employees at Vocational High School YPLP PGRI 1 Makassar. Therefore, to achieve these objectives researchers used data collection techniques with observation, questionnaires, interviews, and documentation with a population of 24 people. And the data is processed using the quantitative descriptive analysis to determine the extent of the effectiveness of interpersonal communication among employees at the Vocational High School YPLP PGRI 1 Makassar. The results of this study indicate that the Effectiveness of Interpersonal Communication among Vocational High School YPLP PGRI 1 Makassar staff with indicators namely: openness with a percentage reaching 90.83 percent, empathy with a percentage reaching 90.56 percent, supportiveness with a percentage of 83.13 percent, positiveness with a percentage reaching 89.44 percent and equality with a percentage reaching 92.08 percent of all the indicators are in the very good category. This is demonstrated through overall data analysis which shows the percentage reached 89.08 percent, the value is in line with related observations made by researchers in the field.
\end{abstract}

Keywords: Effectiveness; interpersonal communication; employees

\section{INTRODUCTION}

Basically, education is something that is universal and continues uninterrupted from generation to generation anywhere in the world (Arhas, 2018; Niswaty \& Arhas, 2019). The principle of such education implies that education is attached to the human self, because with it humans can continually increase their independence as individuals and as members of society, increase their sense of fulfillment and aim at self-actualization. In relation to the environment, they can adapt adaptively and creatively to the challenges of the times. (Akcay \& Akyol, 2012; Akçay \& Akyol, 2014; Gewirth, 2009; Mozahem \& Adlouni, 2020).

As human social beings in everyday life always want to relate to other humans. He wants to know the surrounding environment, even wants to know what is happening in him. This curiosity forces humans to communicate (Arulchelvan \& Elangovan, 2017; Lee \& Kim, 2020; Mitrofan \& Bulborea, 2013). Communication is a process of interaction, the function of communication is as social communication, which implies that communication is important to develop self-concept, self-actualization, for survival, to obtain happiness, avoid stress and 


\section{8| Jurnal Office: Jurnal Pemikiran Ilmiah dan Pendidikan Administrasi Perkantoran \\ Vol. 6, No. 1, January-June 2020, Page 17-24}

tension, among others through communication that is entertaining and fostering relationships with other people (Hung \& Lin, 2013; Kala, Bolia, \& Sushil, 2020).

According to Nurhadi (2017), that the importance of studying communication can be categorized into two things, namely; general aspects and special aspects. The first aspect aims to gain an understanding of the knowledge associated with the communication process. The second aspect is expected to be able to guide humans to be able to: a) change attitudes (to change the attitude); b) change opinions/views (to change the opinion); c) change the behavior; and d) change the society.

Communication has an important role in an organization, especially in school organizations (Brouwer, Downey, \& Bokhove, 2020; Hillemeier, Gusic, \& Bai, 2006). School is one form of formal organization in which there is a school organizational structure consisting of the Principal, Teachers, employees, and students. An effective communication process is needed in an organization so that organizational goals can be achieved.

The implementation of ineffective communication can disrupt all plans, instructions, suggestions, instructions, resulting in chaotic work and organizational goals are not achieved (Nasrullah, 2017; Syaekhu, 2018). Communication is an important issue because many violations occur because perpetrators do not know that they are outside the path of order. This also causes the inadequacy of receiving feedback, due to differences in the perceptions of each employee in the meaning of the information they receive, so that there are often errors when performing tasks that should not need to happen, which in turn will inevitably work they must do it over and over again, and that causes delays in the time of submission of the task (Ferris et al., 2007; Kazakovs, Verdina, \& Arhipova, 2015; Sinambela, 2016). To overcome these problems, it is necessary to implement and implement effective communication that can improve employee morale and performance in an organization, so that with good performance, the goals set can be more easily achieved well. If good communication is created, employee performance will improve, so that goal is expected to be achieved.

In life, it has become essentially necessary for each other. That is what makes interpersonal relationships a must, good interpersonal relationships always require good communication and interaction. Openness, supportive attitude, and positive attitude that can less affect the quantity and quality of interpersonal relationships with each individual. This indicates a lack of effective communication between employees. Interpersonal communication is important because it can improve emotional relationships between employees so that in carrying out their duties and responsibilities can be carried comfortably. Interpersonal communication will also improve the quality and quantity of employee performance because the tasks carried out are carried out without pressure.

\section{METHOD}

The approach used in this research is a quantitative approach. Quantitative approach is an approach that uses numbers in the presentation of data and analysis that uses statistical tests. This type of research is descriptive quantitative that aims to find a picture of the effectiveness of 
interpersonal communication among employees at Vocational High School YPLP PGRI 1 Makassar.

Data measurement is the procedure of assigning numbers to an object in order to express the characteristics of the object. To measure this variable using a questionnaire instrument (questionnaire) using a Likert scale arranged based on variable indicators. With a Likert scale, the variables to be measured are translated into indicator variables. Then the indicator is used as a starting point for arranging instrument items which can be statements and questions (Sugiyono, 2012)

Measurements for each instrument using categories namely $81 \%-100 \%$ are categorized very good, $61 \%-80 \%$ are categorized as good, $41 \%-60 \%$ are categorized quite well, $21 \%$ $40 \%$ are categorized as poor and below $20 \%$ are categorized as not good (Arikunto, 2013)

The population used in this study were all Civil Servants, Non-permanent/Honorary Employees, and Administrative Staff in Vocational High School PLP PGRI 1 Makassar as many as 24 people. Because the population is less than 100 , this study is a population study, that is the population determined is also a sample. Data collection techniques used were observation, questionnaire, interview, and documentation. While the data analysis technique used is the percentage descriptive technique.

\section{RESULT AND DISCUSSION}

The data presented in this study are data obtained from the percentage of questionnaires that have been given to 24 student employees who become research samples intended to determine the effectiveness of interpersonal communication among employees at Vocational High School YPLP PGRI 1 Makassar described as follows:

\section{Openness}

Based on the results of data processing, the indicator of openness is in the very good category, which is $90,83 \%$. This is viewed from the employee's always self-disclosure, always conveying an important matter, and always providing information honestly. In the interaction between employees is very diverse, there are those who are able to casually tell the things they feel to others, on the other hand, there are also people who have never been able to intend to speak openly to people, the attitude of silence that is shown and does not want to tell does not mean he does not trust people differently but indeed for some people there are some things that he really does not want to share with anyone because for him the problem he is experiencing is only his and there is no need for anyone else to know because each individual is different and has his own way to his personal problems, just appreciating the decision he chooses and still establishing good communication between fellow employees because knowing someone does not mean we know all the stories and stories of his life

\section{Empathy}

Based on the results of data processing, the empathy indicator is in the very good category, which is $90,56 \%$. This is seen from employees always showing an interest in what is 


\section{0| Jurnal Office: Jurnal Pemikiran Ilmiah dan Pendidikan Administrasi Perkantoran}

Vol. 6, No. 1, January-June 2020, Page 17-24

being said, always understanding how others feel, and always providing assistance. This is reinforced by the observation that if there is one employee experiencing disaster and the obligation of other employees to reduce their burdens by entertaining, providing support, and making donations to help their difficult times, or there are families of employees who are sick and require large costs because of the costs used inadequate then the obligation as a fellow employee to provide assistance in the form of materials to reduce the burden of his life

\section{Supporting Attitude}

Based on the results of data processing, the support attitude indicator is in the very good category, namely $83.13 \%$. This is seen from employees always not judging the words of employees when communicating, always giving spontaneous thought guidance, always giving guidance in the form of frank advice, and always thinking provisionally. If one of the employees or school residents, be it a teacher, principal or student who is experiencing problems, the other employee always provides guidance in the form of suggestions what they should do in the future and try to help solve the problems faced

\section{Positive Attitude}

Based on the results of data processing, the positive attitude indicator is in the very good category, which is $89.44 \%$. This is viewed from employees always Provide Positive Assessments When communicating, always respecting when communicating, providing solutions when communicating, always accepting suggestions when communicating, always positioning yourself as an important person providing information while communicating, always providing valuable information when communicating. Employees always respect the other person when communicating. This is in line with the observation of researchers that when talking, employees always listen to what is spoken by others by confronting themselves with the interlocutors and become listeners and speakers with each other and speak with good speech

\section{Equality}

Based on the results of data processing, the positive attitude indicator is in the very good category, which is $92.08 \%$. this is in terms of employees always putting themselves equal when communicating, always communicating with anyone, always providing equal opportunities in expressing thoughts, always respecting every opinion when communicating. In Vocational High School YPLP PGRI 1 Makassar, in communicating, it does not differentiate between civil servants or non-civil servants, students and guests, in communication it does not discriminate and provides equal opportunities. Communication is always based on that communication needs to be done well 


\section{Discussion}

\section{Openness}

Openness in communication is interpreted as a person must have the intention to open up, his willingness to convey important information, and provide information honestly to the opponents of the ceremony. Especially the employees in the school organization must implement an attitude of openness without hiding any information.

The closeness between employees not only in work activities but in activities outside of work can also make a good atmosphere for fellow employees, which ultimately good relations between employees will carry over to the work as well. The second aspect of openness refers to the willingness of communicators to convey important, important information that is very necessary to know by fellow employees because it involves organizational information, this also concerns the openness of employees in conveying information in an organization. The third aspect is to provide information honestly, communicators/employees always provide information honestly because dishonesty will cause misunderstanding in communication and cause mistrust with others and interpersonal communication becomes unkind..

\section{Empathy}

Employees always share what other employees feel, sometimes the employee is having a problem so other employees also take part in the problem by asking first the problem than giving a solution or a solution that can be taken for good, and finally, the employee's atmosphere becomes good again and can work as usual without any pressure. The principle of empathy for employees is based on a feeling of mutual care, mutual understanding of what is felt by others (employees) the sense of unity between employees can make the emotional relationship get stronger as already done by Employees at Vocational High School YPLP PGRI 1 Makassar.

\section{Supporting Attitude}

Supporting attitude can be interpreted as a person's sense of enthusiasm in doing a job will appear depending on the motivation and trust given in an organization. Support includes three things. First, descriptiveness, an atmosphere that is descriptive and not evaluative. Second, spontaneity is understood as a person's ability to communicate spontaneously and frankly in conveying his thoughts. Third, provisionalism, is understood as the ability to think openly. In interpersonal communication within an organization, communication will succeed if it has a spontaneous attitude and frank in conveying his thoughts without judging the words of others as has been applied by employees at Vocational High School YPLP PGRI 1 Makassar.

\section{Positive Attitude}

A positive attitude is defined as giving a positive assessment to others when communicating, respecting, and appreciating and accepting someone's advice when 
22 Jurnal Office: Jurnal Pemikiran Ilmiah dan Pendidikan Administrasi Perkantoran

Vol. 6, No. 1, January-June 2020, Page 17-24

communicating and thinking of themselves as important and valuable people when communicating with others. Every employee must implement this positive attitude so that in communicating with colleagues employees run effectively.

\section{Equality}

Equality is defined as someone putting himself on equal terms when communicating regardless of his position, communicating with anyone without discrimination, and always giving equal opportunities to every employee in expressing his thoughts, and respecting every opinion expressed by employees when communicating in the school environment. Equality is the same feeling as other people, as human beings are not high or low, although there are differences in certain abilities, family backgrounds, or other attitudes toward it. Equality is an attitude of treating others horizontally and democratically, not showing oneself higher or better than others because of status, power, intellectual ability, wealth or beauty.

\section{CONCLUSION}

Based on the results of the study it can be concluded that the personal communication between the employees of Vocational High School YPLP PGRI 1 Makassar from the five indicators is included in the category of Very Good with a percentage of 89.08 percent. This can be seen from the results of the research obtained from each indicator on the variables of this study, namely: openness, the effectiveness of interpersonal communication among employees at Vocational High School YPLP PGRI 1 Makassar shows the results that are very well encoded; Empathy, the effectiveness of interpersonal communication among employees at Vocational High School YPLP PGRI 1 Makassar 1 shows that the results are very well encrypted; Supporting Attitudes, the effectiveness of interpersonal communication among employees at Vocational High School YPLP PGRI 1 Makassar shows the results that are very well encrypted; A positive attitude, the effectiveness of interpersonal communication among employees at Vocational High School YPLP PGRI 1 Makassar showed that the results were very well encrypted; Equality, the effectiveness of interpersonal communication among employees at Vocational High School YPLP PGRI 1 Makassar showed very good results that were encrypted.

\section{REFERENCES}

Akcay, C., \& Akyol, B. (2012). Self Actualization Needs and Education of Participants in Lifelong Education Centers. Procedia - Social and Behavioral Sciences, 46, 3456-3459. https://doi.org/https://doi.org/10.1016/j.sbspro.2012.06.084

Akçay, C., \& Akyol, B. (2014). Self-actualization Levels of Participants in Lifelong Education 
Centers. Procedia - Social and Behavioral Sciences, 116, 1577-1580. https://doi.org/https://doi.org/10.1016/j.sbspro.2014.01.437

Arhas, S. H. (2018). Metode Pembelajaran Black Knight. Apa? Mengapa? dan Bagaimana? Jurnal Ad'ministrare, 5(2), 165-172.

Arulchelvan, S., \& Elangovan, R. (2017). Effective Communication Aproaches in Tuberculosis control: Health Workers' Perceptions and Experiences. Indian Journal of Tuberculosis, 64(4), 318-322. https://doi.org/https://doi.org/10.1016/j.ijtb.2016.11.017

Brouwer, J., Downey, C., \& Bokhove, C. (2020). The development of communication networks of pre-service teachers on a school-led and university-led programme of initial teacher education in England. International Journal of Educational Research, 100, 101542. https://doi.org/https://doi.org/10.1016/j.ijer.2020.101542

Ferris, G. R., Perrewé, P. L., Ranft, A. L., Zinko, R., Stoner, J. S., Brouer, R. L., \& Laird, M. D. (2007). Human Resources Reputation and Effectiveness. Human Resource Management Review, 17(2), 117-130. https://doi.org/https://doi.org/10.1016/j.hrmr.2007.03.003

Gewirth, A. (2009). Self-fulfillment. In Self-Fulfillment. https://doi.org/10.2307/2693627

Hillemeier, M. M., Gusic, M., \& Bai, Y. (2006). Communication and Education About Asthma in Rural and Urban Schools. Ambulatory Pediatrics, 6(4), 198-203. https://doi.org/https://doi.org/10.1016/j.ambp.2006.04.004

Hung, K.-P., \& Lin, C.-K. (2013). More Communication is not always Better? The Interplay between Effective Communication and Interpersonal Conflict in Influencing Satisfaction. Industrial Marketing Management, 42(8), 1223-1232. https://doi.org/https://doi.org/10.1016/j.indmarman.2013.05.002

Kala, K., Bolia, N. B., \& Sushil. (2020). Waste management communication policy for effective citizen awareness. Journal of Policy Modeling, 42(3), 661-678. https://doi.org/https://doi.org/10.1016/j.jpolmod.2020.01.012

Kazakovs, M., Verdina, A., \& Arhipova, I. (2015). Automation of Human Resources Development Planning. Procedia Computer Science, 77, 234-239. https://doi.org/https://doi.org/10.1016/j.procs.2015.12.379

Lee, K. R., \& Kim, E. J. (2020). Relationship between Interprofessional Communication and Team Task Performance. Clinical Simulation in Nursing, 43, 44-50. https://doi.org/https://doi.org/10.1016/j.ecns.2020.02.002

Mitrofan, N., \& Bulborea, A. (2013). The Role of Organizational Communication in Structuring Interpersonal Relationships. Procedia - Social and Behavioral Sciences, 76, 511-515. https://doi.org/https://doi.org/10.1016/j.sbspro.2013.04.155

Mozahem, N. A., \& Adlouni, R. O. (2020). Using Entrepreneurial Self-Efficacy as an Indirect Measure of Entrepreneurial Education. The International Journal of Management Education, 100385. https://doi.org/https://doi.org/10.1016/j.ijme.2020.100385 
24| Jurnal Office: Jurnal Pemikiran Ilmiah dan Pendidikan Administrasi Perkantoran

Vol. 6, No. 1, January-June 2020, Page 17-24

Nasrullah, N. (2017). Communication Strategies Employed by the Fourth Semester Students of English Department of State University of Makassar. Jurnal Ad'ministrare: Jurnal Pemikiran Ilmiah Dan Pendidikan Administrasi Perkantoran, 4(2), 83-96.

Niswaty, R., \& Arhas, S. H. (2019). The Effect of Learning Media on Progress Quality in Office Administration Program in Vocational School Negeri 1 Watampone Bone Regency. Journal of Physics: Conference Series, 1387. https://doi.org/10.1088/1742$6596 / 1387 / 1 / 012042$

Sinambela, L. P. (2016). Manajemen Sumber Daya Manusia, Membangun Tim Kerja yang Solid untuk Meningkatkan Kinerja.

Sugiyono. (2012). Metode Penelitian Administrasi Dilengkapi dengan Metode R\&D. In Bandung: Alfabeta. https://doi.org/10.1007/s11116-011-9347-8

Suharsimi, A. (2013). Prosedur Penelitian: Suatu Pendekatan Praktik (Edisi Revisi). Jakarta: Rineka Cipta. https://doi.org/10.1017/CBO9781107415324.004

Syaekhu, A. (2018). Effect of Personality and Interpersonal Communication on Organizational Commitment. Jurnal Ilmiah Ilmu Administrasi Publik, 8(1), 61-68. 